ano 15 - n. 61 I julho/setembro - 2015

Belo Horizonte I p. 1-270 I ISSN 1516-3210

A\&C - R. de Dir. Administrativo \& Constitucional

Revista de Direito ADMINISTRATIVO \& CONSTITUCIONAL

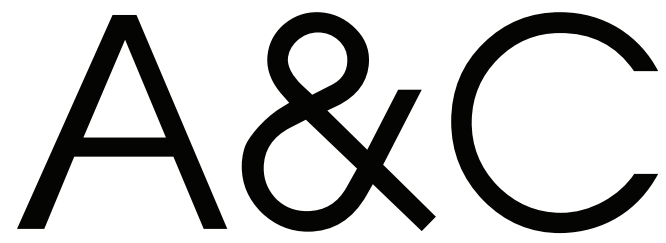




\section{A\&C - REVISTA DE DIREITO ADMINISTRATIVO \& CONSTITUCIONAL}

IPDA

Instituto Paranaense

de Direito Administrativo
ROMEU DEUPE

BACELLAR

๑) 2015 Editora Fórum Ltda.

Todos os direitos reservados. É proibida a reprodução total ou parcial, de qualquer forma ou por qualquer meio eletrônico ou mecânico, inclusive através de processos xerográficos, de fotocópias ou de gravação, sem permissão por escrito do possuidor dos direitos de cópias (Lei no 9.610, de 19.02.1998).

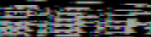

Luís Cláudio Rodrigues Ferreira

Presidente e Editor

Av. Afonso Pena, 2770 - 16ํandar - Funcionários - CEP 30130-007 - Belo Horizonte/MG - Brasil - Tel.: 08007043737 www.editoraforum.com.br / E-mail: editoraforum@editoraforum.com.br

Impressa no Brasil / Printed in Brazil / Distribuída em todo o Território Nacional

Os conceitos e opiniões expressas nos trabalhos assinados são de responsabilidade exclusiva de seus autores.

A246 A\&C : Revista de Direito Administrativo \&
Constitucional. - ano 3, n. 11, jan./mar.
2003)- . - Belo Horizonte: Fórum, 2003-
Trimestral
ISSN: 1516-3210
Ano 1, n. 1, 1999 até ano 2, n. 10, 2002 publicada
pela Editora Juruá em Curitiba
$\begin{aligned} & \text { 1. Direito administrativo. 2. Direito constitucional. } \\ & \text { I. Fórum. } \\ & \text { CDD: } 342 \\ & \text { CDU: } 342.9\end{aligned}$

Supenvisão editorial: Leonardo Eustáquio Siqueira Araújo

Capa: Igor Jamur

Projeto gráfico: Walter Santos

\section{Periódico classificado no Estrato A1 do Sistema Qualis da CAPES - Área: Direito.}

Revista do Programa de Pós-graduação do Instituto de Direito Romeu Felipe Bacellar (Instituição de Pesquisa e Pós-Graduação), em convênio com o Instituto Paranaense de Direito Administrativo (entidade associativa de âmbito regional filiada ao Instituto Brasileiro de Direito Administrativo). A linha editorial da $A \& C$ - Revista de Direito Administrativo \& Constitucional segue as diretrizes do Programa de Pós-Graduação do Instituto de Direito Romeu Felipe Bacellar em convênio com o Instituto Paranaense de Direito Administrativo. Procura divulgar as pesquisas desenvolvidas na área de Direito Constitucional e de Direito Administrativo, com foco na questão da efetividade dos seus institutos não só no Brasil como no direito comparado, com ênfase na questão da interação e efetividade dos seus institutos, notadamente América Latina e países europeus de cultura latina.

A publicação é decidida com base em pareceres, respeitando-se o anonimato tanto do autor quanto dos pareceristas (sistema double-blind peer review).

Desde o primeiro número da Revista, $75 \%$ dos artigos publicados (por volume anual) são de autores vinculados a pelo menos cinco instituições distintas do Instituto de Direito Romeu Felipe Bacellar.

A partir do volume referente ao ano de 2008 , pelo menos $15 \%$ dos artigos publicados são de autores filiados a instituições estrangeiras.

Esta publicação está catalogada em:

- Ulrich's Periodicals Directory

- RVBI (Rede Virtual de Bibliotecas - Congresso Nacional)

- Library of Congress (Biblioteca do Congresso dos EUA)

A\&C - Revista de Direito Administrativo \& Constitucional realiza permuta com as seguintes publicações: - Revista da Faculdade de Direito, Universidade de São Paulo (USP), ISSN 0303-9838

- Rivista Diritto Pubblico Comparato ed Europeo, ISBN/EAN 978-88-348-9934-2 
Diretor-Geral

Romeu Felipe Bacellar Filho

Diretor Editorial

Paulo Roberto Ferreira Motta

Editores Acadêmicos Responsáveis

Daniel Wunder Hachem

Ana Cláudia Finger

Assessor Editorial

Felipe Klein Gussoli

\section{Conselho Editorial}

Adilson Abreu Dallari (PUC-SP) Juan Pablo Cajarville Peluffo (Universidad de La República - Uruguai) ardo Schier (Instituto Bacellar) Justo J. Reyna (Universidad Nacional del Litoral - Argentina)

Alice Gonzalez Borges (UFBA) Juarez Freitas (UFRGS)

Carlos Ari Sundfeld (FGV-SP) Luís Enrique Chase Plate (Universidad Nacional de Asunción - Paraguai)

Carlos Ayres Britto (UFSE) Marçal Justen Filho (UFPR)

Adriana da Costa Ricardo Schier (Instituto Bacellar)
Alice Gonzalez Borges (UFBA)

Marcelo Figueiredo (PUC-SP)

Márcio Cammarosano (PUC-SP)

Carlos Delpiazzo (Universidad de La República - Uruguai) Cármen Lúcia Antunes Rocha (PUC Minas) Célio Heitor Guimarães (Instituto Bacellar) Celso Antônio Bandeira de Mello (PUC-SP) Clèmerson Merlin Clève (UFPR) Clovis Beznos (PUC-SP) Edgar Chiuratto Guimarães (Instituto Bacellar) Maria Cristina Cesar de Oliveira (UFPA)

Nelson Figueiredo (UFG)

Odilon Borges Junior (UFES)

Pascual Caiella (Universidad de La Plata - Argentina)

Emerson Gabardo (UFPR)

Paulo Eduardo Garrido Modesto (UFBA)

Paulo Henrique Blasi (UFSC)

Enrique Silva Cimma (Universidad de Chile - Chile) Eros Roberto Grau (USP)

Irmgard Elena Lepenies (Universidad Nacional del Litoral - Argentina) de La Coruña - Espanha)

Pedro Paulo de Almeida Dutra (UFMG)

Regina Maria Macedo Nery Ferrari (UFPR)

Rogério Gesta Leal (UNISC)

Rolando Pantoja Bauzá (Universidad Nacional de Chile - Chile)

Sergio Ferraz (PUC-Rio)

Valmir Pontes Filho (UFCE)

José Eduardo Martins Cardoso (PUC-SP)

José Luís Said (Universidad de Buenos Aires - Argentina) José Mario Serrate Paz (Universidad de Santa Cruz - Bolívia)

Yara Stroppa (PUC-SP)

\section{Homenagem Especial}

Guillermo Andrés Muñoz (in memoriam) Jorge Luís Salomoni (in memoriam) Julio Rodolfo Comadira (in memoriam) Lúcia Valle Figueiredo (in memoriam)

Manoel de Oliveira Franco Sobrinho (in memoriam) Paulo Neves de Carvalho (in memoriam) 


\title{
O regime jurídico das Parcerias Voluntárias com as Organizações da Sociedade Civil: inovações da Lei no 13.019/2014
}

\author{
Cristiana Fortini \\ Professora de Direito Administrativo da Faculdade de Direito da Universidade Federal de Minas \\ Gerais -UFMG (Belo Horizonte - MG). Doutora em Direito Administrativo pela UFMG. Membro \\ da Diretoria do Instituto Brasileiro de Direito Administrativo. Advogada. Ex-Controladora Geral \\ e Ex-Procuradora Geral Adjunta de Belo Horizonte. E-mail: <crisfortini@uol.com.br>.
}

\section{Priscila Giannetti Campos Pires}

Pós-graduanda em Direito da Infraestrutura na GVlaw (São Paulo - SP). Bacharel em Direito pela Universidade Federal de Minas Gerais. Advogada. E-mail: <prigiannetti@hotmail.com>.

\begin{abstract}
Resumo: O presente estudo aborda os contornos das parcerias voluntárias celebradas entre o Estado e o Terceiro Setor, disciplinadas pela Lei oㅜ 13.019/2014. Trata-se de importante instrumento que estabelece o regime jurídico aplicável a tais acordos, afastando o disposto no artigo 116 da Lei no 8.666/93, bem como definindo enquadramento de Organizações da Sociedade Civil, a forma de seleção dessas entidades, as novas modalidades de parceria, a forma de execução e prestação de contas dos ajustes e os meios de fiscalização. Inicialmente o presente artigo pretende analisar a constitucionalidade da citada lei, para, em seguida, descrever as principais inovações trazidas por esta. 0 trabalho aponta que o diploma legal institui importante marco regulatório para as relações de colaboração, estabelecendo parâmetros com o intuito de dar maior legitimidade e transparência aos ajustes firmados entre os entes públicos e privados. Em que pese tal ponto, questiona-se a competência da União para estabelecer regra geral sobre a matéria.
\end{abstract}

Palavras-chave: Parcerias voluntárias. Terceiro Setor. Colaboração. Organizações da Sociedade Civil.

Sumário: 1 Introdução - 2 Fundamento da Lei № 13.019/2014 - 3 Conceitos das Organizações da Sociedade Civil e requisitos formais para enquadramento nos termos da Lei no $13.019 / 2014$ 4 Instrumento de formalização das parcerias: Termo de Colaboração e Termo de Fomento - 5 Obrigatoriedade de seleção das Organizações da Sociedade Civil por Chamamento Público - $\mathbf{6}$ Conclusões - Referências

\section{Introdução}

O regime jurídico aplicável às relações entre a Administração Pública e o Terceiro Setor ${ }^{1}$ é tema que desperta a atenção de estudiosos e suscita questionamentos

\footnotetext{
1 A expressão "terceiro setor" nasce no contexto da Reforma administrativa do Estado idealizada e implementada, em certa medida, na década de 90 do século passado. A nova terminologia visava abarcar as entidades criadas fora do ambiente estatal, desprovidas de interesse lucrativo e voltadas ao atendimento de demandas socialmente relevantes.
} 
relevantes. A discussão é impulsionada pela ideologia oficial que alimentou (e ainda alimenta) o estreitamento das parcerias entre entes públicos e privados, inspirada pela busca de eficiência e otimização de resultados. ${ }^{2}$ A avaliação de que a cooperação privada produziria resultados mais satisfatórios, quando comparados aos decorrentes da atuação direta pelas entidades e órgãos públicos, vez por outra enfrenta críticas importantes $^{3}$ alimentadas pelo perfil não liberal da Constituição brasileira. ${ }^{4}$

Os calorosos debates foram e continuam sendo alavancados pela pluralidade de leis federais voltadas à disciplina das distintas entidades integrantes do conceito de terceiro setor e seus modelos de ajuste com o Poder Público e o expressivo volume de recursos públicos a elas transferidos. ${ }^{5}$ Outro fator de aquecimento são as denúncias que volta e meia estampam o noticiário e sugerem a ocorrência de condutas descompassadas dos princípios vetores da administração pública quer na escolha das entidades, quer na fiscalização dos seus afazeres.

Sob esse prisma, cite-se a Comissão Parlamentar de Inquérito (CPI) ${ }^{6}$ instaurada em 2001, pelo Senado Federal, que teve como origem a apuração de denúncias vinculadas pela imprensa, que apontavam a atuação irregular da Associação Amazônia na compra de 172 mil hectares de terras públicas em Roraima, bem como a interferência em assuntos indígenas, ambientais e de segurança nacional na região fronteiriça. ${ }^{7}$ Naquela oportunidade, identificou-se a necessidade de aperfeiçoamento legislativo, com o fito de construir mecanismos eficazes de controle das atividades dessas organizações, quando subsidiadas por verbas públicas.

2 Nesse sentido, afirma Gabriel Placha que "O modelo atual é de eficiência, com o Estado dirigindo o processo por meio da atividade regulatória, e a estrutura para isso não envolve apenas as entidades reguladoras, mas o próprio Poder Público na qualidade de agente regulador e não prestador de direito para atender a todas as necessidades coletivas" (PLACHA, Gabriel. Os impactos e as perspectivas da regulação estatal sobre as atividades econômicas. Revista de Direito Econômico e Socioambiental, Curitiba, v. 1, n. 2, p. 251-270, jul./dez. 2010. p. 253).

3 Sobre esse debate, ver: NOHARA, Irene Patrícia. Desafios jurídicos das Parcerias Público-Privadas (PPPs) e desenvolvimento nacional sustentável. Revista de Direito Econômico e Socioambiental, Curitiba, v. 5, n. 2, p. 184-203, jul./dez. 2014. p. 187-190.

4 A respeito da natureza dirigente da Constituição brasileira, ver: BERCOVICI, Gilberto. Revolution trough Constitution: the Brazilian's directive Constitution debate. Revista de Investigações Constitucionais, Curitiba, v. 1, n. 1, p. 7-18, jan./abr. 2014, e HACHEM, Daniel Wunder. A noção constitucional de desenvolvimento para além do viés econômico: reflexos sobre algumas tendências do Direito Público brasileiro. A\&C - Revista de Direito Administrativo \& Constitucional, Belo Horizonte, ano 13, n. 53, p. 133-168, jul./set. 2013. Para uma análise das diferentes concepções de Constituição ao longo das transformações ocorridas entre o século XVIII e o XX, das mais liberais às mais sociais, conferir: NOBRE JÚNIOR, Edilson Pereira. Uma ideia de Constituição. Revista de Investigações Constitucionais, Curitiba, v. 1, n. 1, p. 111-145, jan./abr. 2014.

5 São interessantes as considerações feitas por: SUNDFELD, Carlos Ari; SOUZA, Rodrigo Pagani de. As modernas parcerias públicas com o Terceiro Setor. A\&C - Revista de Direito Administrativo \& Constitucional, Belo Horizonte, ano 11, n. 43, p. 57-89, jan./mar. 2011.

6 Requerimento 으 22/2001.

7 Nesse sentido, assim sugeriu a Relatora, Sra. Senadora Marluce Pinto, no âmbito do Relatório Final da citada CPI à fl. 197: "Cumpre, portanto, instituir um sistema de inscrições de ONGs em cadastro específico, estaduais ou de caráter nacional, bem como obrigar órgãos públicos federais e estaduais, bem assim Cortes de Contas, a instituir um cadastro de ONGs que recebam verbas públicas, e correspondente e adequado sistema de controle" (Disponivel em: <http://www.senado.gov.br/atividade/materia/getPDF.asp?t=56352\&tp=1>. Acesso em: 20 maio 2015). 
Passados alguns anos, nova CPI foi instaurada no âmbito do Senado Federal, ${ }^{8}$ com o intuito de investigar denúncias sobre irregularidades nos repasses do governo federal, durante o último mandato do governo Fernando Henrique Cardoso e primeiro mandato do Presidente Lula, para entidades do terceiro setor, tais como ONGs e OSCIPs. Novamente, destaca-se nas conclusões do trabalho da CPI a constatação da inexistência na legislação federal de mecanismos eficazes para seleção de entidade, fiscalização da execução do objeto do convênio, bem como de punição em caso de

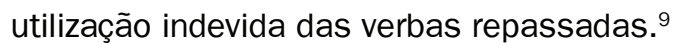

$\mathrm{Na}$ tentativa de fazer frente a tais denúncias e dar uma resposta à opinião pública, o Executivo, por intermédio da Portaria nº 392/2012, criou grupo de trabalho interministerial, tendo como principal objetivo "elaborar proposta para o aperfeiçoamento da metodologia de prestações de contas de convênios, contratos de repasse, termos de parceria e instrumentos congêneres celebrados pelos órgãos e entidades da administração pública federal com entidades privadas sem fins lucrativos". Esse estudo, inclusive, foi considerado durante as discussões que resultaram no novo marco regulatório das parcerias entre administração pública e entidades privadas. ${ }^{10}$

Até o advento da Lei no 13.019/14, os diplomas legais de conhecimento e compreensão obrigatórios, a envolver a presente temática, eram, substancialmente, as Leis Federais nos 8.958/94, 9.637/1998 e 9.790/1999, que disciplinam, respectivamente, as fundações de apoio, as organizações sociais (OS) e as organizações da sociedade civil de interesse público (OSCIP).

Para além das citadas leis, e antes do seu surgimento, a relação entre entidades privadas e o poder público mereceu especial atenção por parte do legislador responsável pela edição da Lei Geral de Licitações e Contratos (Lei no 8.666/93) que, em seu art. 116, regulou aspectos importantes sobre os convênios público-privados, revelando nítida preocupação com a correta aplicação dos recursos públicos transferidos.

A redação do art. 116 gerou dúvidas quanto à necessidade de licitação para a seleção das entidades, bem como sobre a metodologia de avaliação da atuação privada, entre outros aspectos.

Isto porque parcela considerável da doutrina considera que a disposição "no que couber", inscrita na regra do art. 116 da Lei no 8.666/93, não impõe a aplicação a estes ajustes do regime dos contratos administrativos, ${ }^{11}$ principalmente em razão

8 Essa Comissão foi criada através do Requerimento № 201/2007.

9 Nesse sentido, vide conclusões apresentadas no Relatório Final da "CPI das ONGs", fls. 1.370/1.405. Disponivel em: <http://www2.senado.leg.br/bdsf/bitstream/handle/id/194594/CPlongs.pdf?sequence=6>.

10 Tal fato foi exaltado pelo I. Senador Rodrigo Rollemberg, relator pelo Parecer no $1.548 / 2013$, elaborado pela Comissão de Meio Ambiente, Defesa do Consumidor e Fiscalização e Controle (fl. 02). Disponível em: <http:// www.senado.gov.br/atividade/materia/getPDF.asp?t=137799\&tp=1>. Acesso em: 24 maio 2015.

11 Nesse sentido leciona Carvalho Filho: “A celebração de convênios, por sua natureza, impende de licitação prévia como regra. É verdade que a Lei no $8.666 / 93$ estabelece, no art. 116, que é ela aplicável a convênios e outros acordos congêneres. Faz, entretanto, a ressalva de que a aplicação ocorre no que couber" (CARVALHO FILHO, José dos Santos. Manual de direito administrativo. 5. ed. São Paulo: Atlas, 2012. p. 244). 
da natureza desses ajustes, que supostamente revelariam interesses institucionais comuns e convergentes.

Verifica-se na apresentação de motivos para o Projeto de Lei no 649/11, de autoria do Senador Aloysio Nunes Ferreira, do qual é oriunda a Lei no 13.019/14, a crítica ao "regramento singelo" oferecido pelo art. 116, considerando-o tímido, "aquém da necessidade de legislação a respeito dos acordos e parcerias entre o Estado e o Terceiro Setor". A despeito de reconhecer a existência de normas aplicáveis à esfera federal, como a IN № 1/97, editada pela Secretaria do Tesouro Nacional e o Decreto ํㅜ 6.170/07, e sem embargo de recordar a existência das Leis nos 9.637/98 e 9.790/99, a manifestação do Senador destacava a pretensão de "estabelecer um marco legislativo amplo, que regule de forma abrangente todas as modalidades de acordos e parcerias".

Com a edição da Lei o 13.019/2014,12 pretende-se a criação de marco regulatório dos ajustes celebrados pela Administração Pública com entidades privadas sem fins lucrativos, ${ }^{13}$ estabelecendo regras sobre a seleção dessas entidades, as modalidades de parceria, a forma de execução e prestação de contas, e os meios de fiscalização e de responsabilização dos participantes. Cumpre ressaltar que vários desses parâmetros já eram observados na órbita federal, em razão das determinações da Instrução Normativa da Secretaria do Tesouro Nacional IN/STN no 03/2003, dos Decretos no 3.100 e o 6.170/2007 e da Portaria Interministerial ํo $507 / 11$.

A citada lei não releva repúdio à cooperação e participação privada. Ao contrário, artigos da Lei revelam a preocupação com o fortalecimento da sociedade civil, ${ }^{14}$ por intermédio da participação popular e da gestão pública democrática, ${ }^{15}$ sendo as relações pautadas pelos princípios norteadores da Administração Pública (artigo 37, caput, da Constituição Federal).

Merece destaque o incentivo à participação da sociedade civil por meio da institucionalização do Procedimento de Manifestação de Interesse Social, instrumento pelo qual as organizações da sociedade civil, movimentos sociais ou cidadãos

\footnotetext{
12 O citado diploma tramitou no âmbito do Senado pelo nํ 649, proposto em 2011 pelo Senador Aloysio Nunes Ferreira.

13 A justificativa para o PL expressa a não intenção de regrar os convênios público-público que a Constituição brasileira repetidas vezes menciona, reconhecendo suas características peculiares e a necessidade de disciplina apartada. Por outro lado, como de fato se verifica na Lei no $13.019 / 14$, suas normas não atingem os contratos de gestão celebrados com as Organizações Sociais, mesmo que as oS se enquadrem no conceito de Organização da Sociedade Civil criado pela nova lei.

14 Vide artigo 5으 da Lei ํㅜ 13.019/2014.

15 Trata-se de uma postura do Estado, implementando no âmbito estatal políticas de fomento da atividade privada que objetive a consecução de um interesse público, revelando, conforme leciona Chevallier (2009, p. 60), a preocupação de associar atores sociais à implementação das ações públicas, implementando a gestão delegada aos serviços ditos sociais, culturais ou econômicos, nos níveis nacional e local.
} 
poderão apresentar propostas ao Poder Público visando à celebração os acordos em questão. ${ }^{16}$

A inserção desse novo regramento para a formalização das parcerias entre Administração Pública e as entidades por ela atingidas implica, em um primeiro plano, o afastamento das disposições sobre Licitação e Contratos no âmbito da Lei no 8.666/1993, bem como a legislação atinente aos Convênios. Tal diretriz restou evidente na redação do art. 84, que determina a inaplicabilidade do disposto nesses instrumentos às relações de fomento e colaboração regidas por esta nova lei, a não ser nos casos expressamente determinados em lei. ${ }^{17}$ Resta claro que, por opção legislativa, a disciplina dos Convênios Administrativos cingirá aos ajustes celebrados entre entes públicos, mediante regime de cooperação, passando as relações de fomento ao Terceiro Setor serem regidas por modalidades próprias.

Todavia, a redação do art. 84 suscita uma série de dúvidas. Primeiro porque não se indicou a qual legislação sobre convênio está a se referir o dispositivo. Contudo, o maior "desconforto" emerge do caput do art. 84, segundo o qual os convênios estarão cingidos aos ajustes celebrados entre entes públicos, mediante regime de cooperação. Como será abordado aqui, não pode o legislador ignorar que a palavra convênio está presente na Constituição de forma a envolver relações público-privadas e não apenas os enlaces público-público e porque haverá situações que escaparão do campo de incidência da Lei no 13.019/14, como os convênios celebrados com entidades que possuem ambição lucrativa.

Importa destacar que o projeto de lei previa inicialmente a revogação do artigo 116 da Lei no 8.666/93, além dos artigos 10 e 15 da Lei no 9.790/99, tendo em vista a inserção deste novo regramento jurídico. Contudo, pontuou-se que a revogação desse dispositivo poderia gerar verdadeiro vácuo normativo quanto aos Convênios firmados pelos entes públicos, e aos demais ajustes que, apensar de terem como partícipes o particular, não se enquadram nos termos da Lei no $13.019 / 2014 .{ }^{18}$

\footnotetext{
16 Art. 18. É instituído o Procedimento de Manifestação de Interesse Social como instrumento por meio do qual as organizações da sociedade civil, movimentos sociais e cidadãos poderão apresentar propostas ao poder público para que este avalie a possibilidade de realização de um chamamento público objetivando a celebração de parceria.

17 Art. 84. Salvo nos casos expressamente previstos, não se aplica às relações de fomento e de colaboração regidas por esta Lei o disposto na Lei n 8.666, de 21 de junho de 1993 , e na legislação referente a convênios, que ficarão restritos a parcerias firmadas entre os entes federados.

Parágrafo único. Os convênios e acordos congêneres vigentes entre as organizações da sociedade civil e a administração pública na data de entrada em vigor desta Lei serão executados até o término de seu prazo de vigência, observado o disposto no art. 83.

18 Nesse sentido, destaca-se trecho do Parecer elaborado no âmbito da Comissão de Meio Ambiente, Defesa do Consumidor e Fiscalização e Controle, relatado pelo então Senador Rodrigo Rollemberg: “Em face do imperativo de fundamentar raciocínio ora desenvolvido, adianta-se que não julgamos prudente, nem necessário revogar o art. 116 da Lei $\mathrm{n}$ - 8.666, de 1993. Primeiramente, porque, até o momento, é a única norma geral, com estatura de lei, a disciplinar os convênios. Ocorre que ela se presta a regular não apenas os convênios da Administração Pública com entidades particulares, mas também entre os entes públicos. Assim, a revogação do art. 116 criaria um vácuo legislativo no tocante aos convênios entre órgãos e entidades do Poder Público. Naturalmente, com a aprovação da nova lei, o dispositivo terá seu âmbito de incidência limitado a esses casos."
} 
Feitas essas breves ponderações sobre o contexto em que se insere esse novo regime jurídico, passa-se a expor de forma específica as principais inovações trazidas por esta lei.

\section{Fundamento da Lei no 13.019/2014}

O legislador federal parte da premissa de que os ajustes sem finalidade econômica entre o Poder Público e as organizações da sociedade civil ${ }^{19}$ são modalidades contratuais, motivo pelo qual a União teria competência constitucional para criar regras gerais. Tanto é assim que o PL recorre ao art. 22, XXVII, da Constituição para sustentar a competência da União para editar as normas gerais sobre parcerias que recheiam a Lei $n$ o $13.019 / 14 .^{20}$

Nesse mesmo sentido, concluiu Raquel Melo Carvalho, no Parecer no 15.387/2014, elaborado no âmbito da Advocacia Geral do Estado de Minas Gerias: ${ }^{21}$

Considerando o referido conteúdo da Lei Federal ํo 13.019/2014, entende-se que, apesar da diversidade das expressões, o termo de colaboração e o termo de fomento instrumentalizam acordos que consagram parcerias com atendimento integral dos pressupostos conceituais da figura do contrato administrativo. Com efeito, o contrato administrativo é uma avença firmada entre a Administração e o terceiro contratado, submetida ao regime jurídico de direito público, com obrigações impostas para ambas as partes, sendo lícita a fixação de prerrogativas administrativas em favor do interesse público, com as respectivas contrapartidas aptas a assegurar o equilíbrio do ajuste bilateral No caso de termo de colaboração e do termo de fomento, há um acordo firmado entre o Poder Público e uma organização da sociedade civil com deveres assumidos por ambas as partes; embora haja o interesse comum na cooperação, é certo que o Poder Público busca o atingimento de determinados resultados e a entidade privada pretende usufruir dos incentivos viabilizados pelo estado, sejam de natureza econômica, pessoal, financeira ou patrimonial. A oposição dos objetivos perseguidos pelas partes evidencia a natureza contratual do vínculo, o que o torna claro tratar-se, do ponto de vista jurídico, de um contrato administrativo, com a devida vênia das posições em sentido contrário. (grifo nosso)

\footnotetext{
19 Organização da sociedade civil é nome genérico utilizado pela Lei nำ13.019/14.

20 Afirma o Senador Aloysio, à fl. 53 do Projeto de Lei: “O fundamento constitucional da lei que se pretende criar é o art. 22, XXVII da Constituição Federal, que estabelece a competência privativa da União para legislar a respeito de normas gerias em todas as modalidades de contratação para a Administração Pública em todos os níveis (União, Estado, Distrito Federal, Municípios), incluindo entidades da administração indireta. Esse dispositivo constitucional, é bom frisar é fundamento da Lei no 8.666, de 1993, bem como de seu já mencionado art. 116" (DISPONÍVEL EM: <HTTP://LEGIS.SENADO.LEG.BR/MATEWEB/ARQUIVOS/MATEPDF/98372.PDF>. ACESSO EM: 20 MAIO 2015).

21 CARVALHO, Raquel Melo. Parecer no 15.387/2014. p. 14. Disponível em: <http://www.age.mg.gov.br/ images/stories/downloads/advogado/pareceres2014/parecer-15.387.pdf>. Acesso em: 12 abr. 2015.
} 
Curiosamente, o Projeto de Lei no 649, a despeito de valer-se do citado artigo constitucional, enfatiza o entendimento da doutrina tradicional ${ }^{22}$ que traça distinção entre as espécies de acordos, dividindo-os em convênios (as partes possuem interesses coincidentes) e contratos (marcados pelo antagonismo de pretensões). ${ }^{23}$ Diz a justificativa para o $\mathrm{PL}: 24$

Exatamente porque os acordos nos quais os interesses das partes são coincidentes ("convênios", em sentido amplo") se diferenciam essencialmente dos acordos em que os interesses das partes são antagônicos ("contratos", em sentido estrito), entendemos que esses temas devem ser tratados em leis distintas.

Ora, se convênios e contratos são figuras distintas, tal como afirma o PL, como sustentar a obrigatoriedade de observância dos ditames da Lei no 13.019/14 pela totalidade de entes federados com o fundamento no art. 22, XXVII, da Constituição Federal?

A redação do artigo 22, XXVII, da Constituição Federal é clara ao determinar que cabe à União editar "normas gerais de licitação e contratação, em todas as modalidades, para as administrações públicas diretas, autárquicas e fundacionais da União, Estados, Distrito Federal e Municípios" (grifo nosso).

$\mathrm{Na}$ medida em que se reconhece a identidade dos convênios, não faz sentido apoiar a criação de normas gerais no dispositivo constitucional que nada menciona a esse respeito.

A opção constitucional pelo federalismo importa a autonomia dos múltiplos entes políticos que integram a república para a definição dos seus contornos organizacionais e jurídicos, desde que competência diversa não tenha sido previamente fixada no texto constitucional. ${ }^{25}$ Vale dizer, o texto constitucional original pode, como de fato o fez, criar "cicatrizes" na autonomia federativa, reservando à União a competência para criar normas gerais.

Mas, no silêncio da Constituição, outra conclusão não se pode chegar senão à de que os entes federados decidem, legislam e executam, a seu modo, as políticas

22 Há importantes trabalhos que desconstituem os argumentos clássicos, defendendo a natureza contratual dos convênios, como, por exemplo, a tese sobre Convênios Administrativos, apresentada no programa de pósgraduação da Universidade Federal de Minas Gerais, por Gustavo Alexandre Magalhães.

23 O presente texto enfrentará, mais adiante, a discussão sobre a competência legislativa da União para ditar normas gerais sobre as parcerias.

24 BRASIL. Projeto de Lei nº 649, de 2011. Estabelece o regime jurídico das parcerias entre Administração Pública e entidades privadas sem fins lucrativos para a consecução de finalidades de interesse público. p. 47. Disponível em: <http://www.senado.gov.br/atividade/materia/getPDF.asp?t=98462\&tp=1>. Acesso em: 25 maio 2015.

25 Seria distinto se o constituinte houvesse adotado outra forma de Estado que não a federal. Sobre o modelo de Estado autonômico, por exemplo, adotado na Espanha, conferir: RODRÍGUEZ-ARANA MUÑOZ, Jaime. El Estado autonómico y los nacionalismos. Revista de Investigações Constitucionais, Curitiba, v. 1, n. 3, p. 91-103, set./dez. 2014. 
de colaboração e fomento, aprisionados, obviamente, pelos princípios da administração pública. Há, pois, no mínimo, uma contradição entre os fundamentos do Projeto de Lei.

Mas, ainda que ali se tivesse adotado a doutrina mais recente, que vislumbra identidade/aproximação entre contratos celebrados pela Administração Pública e convênios pactuados com entidades privadas, ${ }^{26}$ ao fundamento que, na prática a essência do vínculo está na remuneração por atividade desempenhada, nada ou pouco destoando de contratos de prestação de serviço, não há como ignorar alguns outros aspectos.

Em primeiro lugar nem todos os convênios (expressão usada na Lei no 8.666/93 e ignorada na Lei no 13.019/14) terão conteúdo que remonte a contratos de prestação de serviço. Haverá casos em que tal paralelismo não se fará possível. Veem-se, por exemplo, situações em que o Poder Público incentiva o privado a assumir compromissos de zelar por espaços públicos sem direito à contraprestação. Também se pode vislumbrar a soma de esforços público e privado visando à realização de um evento, ${ }^{27}$ quando também não se faz pagamento pelo trabalho entregue.

Mas o argumento decisivo está no próprio texto constitucional.

A própria Constituição da República adota ambas as terminologias. Fala-se em contratos, mas também em convênios. Não nos referimos aos convênios público-público, a que alude o artigo 241 da Constituição, mas ao convênio público-privado de que cuida o seu artigo 199, $\$ 1$.

Ora, se a Constituição brasileira prevê a celebração de convênios público-privado não nos parece possível ignorar a intenção de conferir individualidade própria a esse ajuste. Não se pretende ignorar que alguns "convênios" são verdadeiros "contratos de prestação de serviço", rotulados de forma distinta como intuito de escapar da incidência da Lei no 8.666/93, já que seu art. 116 oferece uma válvula de escape ao utilizar a expressão "no que couber". Mas a presença de convênios "fantasia" não basta para aniquilar a possível existência de convênios "genuínos" entre a esfera pública e o setor privado.

Logo, parece-nos faltar respaldo constitucional à pretensão da esfera federal de transpor aos demais entes federados as regras que, no seu sentir, deveriam conduzir a celebração, gestão e fiscalização de vínculos desse jaez.

\footnotetext{
26 Nesse sentido, pondera Gustavo Magalhães: “O argumento de que nos contratos os interesses são contrapostos, por questão de coerência, deveria abranger também os convênios administrativos. Mas ninguém exige a contraposição de interesses como requisito da celebração de convênios. Por essa razão deve ficar claro que a pluralidade de partes pressupõe (tanto para os contratos quanto para os convênios) a divergência de interesses, mas não a contraposição de objetivos. Se nos convênios os interesses fossem comuns, idênticos, não haveria negócio jurídico bilateral (que pressupõe acordo de vontades autônomas), mas sim negócio jurídico unilateral" (MAGALHÃES, Gustavo Alexandre. Convênios Administrativos. Aspectos polêmicos e análise crítica de seu regime jurídico. São Paulo: Atlas, 2012. p. 214, grifo nosso).

27 Não estamos a cuidar de patrocínio, mas de evento executado por ambas as partes.
} 
Importa recordar que boa parte dos dispositivos da Lei no $13.019 / 14$ são inspirados em outras regras federais, com destaque para os Decretos nos $3.100 / 03$, 6.170/07 e a Portaria Interministerial no 507/11. Em certa medida, o legislador quer impor aos demais entes cumprir o que a União já vem realizando.

Há que se deixar claro que não se desconsidera a necessidade de condicionar a celebração das "parcerias" entre Poder Público e as entidades privadas sem fins lucrativos à observância de normas. Logo não se defende a escolha injustificada de entidades, a precariedade do vínculo ou a ausência de fiscalização, em especial porque a própria Constituição já fornece material suficiente para que se refutem ajustes assim. O que se discute é se a União pode dizer como tais aspectos serão observados pelos demais entes.

\section{Conceitos das Organizações da Sociedade Civil e requisitos formais para enquadramento nos termos da Lei ํㅡㄹ 13.019/2014}

Confirmada a inconstitucionalidade da Lei no $13.019 / 14$, nada mais restaria a comentar. Contudo, diante da presunção de constitucionalidade afastada apenas diante de declaração formal pelo órgão judicial competente a fazê-lo, cumpre-nos avançar na avaliação.

O artigo primeiro da Lei no $13.019 / 2014$ define que as normas gerais para parcerias voluntárias serão aplicáveis, de um lado, aos entes políticos ou entidades de sua Administração Indireta, e, de outro, às Organizações da Sociedade Civil, para a consecução de finalidades de interesse público.

Quanto aos entes políticos abrangidos pela legislação, o citado artigo vincula obediência à lei, como já sinalizado, não apenas à União e a Administração Pública Indireta Federal, mas também aos Estados, Distrito Federal, Municípios e às suas autarquias, fundações, empresas públicas e sociedades de economia mista prestadoras de serviço público e suas subsidiárias.

No que tange às organizações sujeitas às regras impostas por esta lei, é essencial atentarmos à definição explicitada pelo art. $2^{\circ}$, I. ${ }^{28}$ Segundo o citado artigo, são consideradas organizações da sociedade civil as pessoas jurídicas de direito privado, sem fins lucrativos, que não distribuam excedentes operacionais, dividendos, bonificações, participações ou parcelas do seu patrimônio aos diretores, sócios, associados, conselheiros, diretores, empregados ou doadores, e que apliquem os

\footnotetext{
28 I - organização da sociedade civil: pessoa jurídica de direito privado sem fins lucrativos que não distribui, entre os seus sócios ou associados, conselheiros, diretores, empregados ou doadores, eventuais resultados, sobras, excedentes operacionais, brutos ou líquidos, dividendos, bonificações, participações ou parcelas do seu patrimônio, auferidos mediante o exercício de suas atividades, e que os aplica integralmente na consecução do respectivo objeto social, de forma imediata ou por meio da constituição de fundo patrimonial ou fundo de reserva;
} 
valores percebidos pelas atividades institucionais, integralmente na consecução do respectivo objeto social.

Ressalta-se que a definição do art. 2ํ, I, é abrangente. A lei é aplicável a qualquer pessoa jurídica de direito privado, sem fins lucrativos, com finalidade de consecução ao interesse público, e que atenda a determinação de não distribuição de lucros ou excedentes.

Porém, o art. 3o, III, ${ }^{29}$ afasta a aplicação do diploma ora estudado aos contratos de gestão, celebrados pelas Organizações Sociais. No âmbito legislativo, o relator da lei limitou-se a fundamentar essa exclusão afirmando que "a proposição não abrange o 'contrato de gestão' com Organização Social, que continua regia unicamente pela Lei n 9.637, de 1998, por significativa incompatibilidade entre seus princípios". ${ }^{30}$

Ressalta-se que essa exclusão estaria restrita aos Contratos de Gestão celebrados por tais entidades, não abrangendo possiveis Termos de Colaboração ou Termos de Parceria. Isto significa que o fato de uma organização ser reconhecida como os não importa na inaplicabilidade da lei, dependendo, isto sim, de qual seria o objeto de parceria.

Tal exclusão seria explicável considerando a missão dessas entidades, substituindo o Poder Público, com o objetivo de atender a sociedade civil na prestação, por exemplo, de atividades de saúde e educação. Trata-se de verdadeira desoneração do Estado, motivo pelo qual se justifica o tratamento diferenciado dessas entidades, quando no âmbito dos contratos de gestão, apto a afastar a aplicação da Lei no $13.019 / 2014 .^{31}$

Além disso, pontua-se que para os ajustes celebrados por OSCIPs aplicam-se as determinações da Lei no $13.019 / 2014^{32}$ apenas no que couber. Nesse ponto, identifica-se outro exercício de difícil execução, isto é, como definir as hipóteses nas quais caberia ou não aplicar à Lei no 13.019/14 tais ajustes. Seria aplicável tudo aquilo que não viola diretamente os ditames da Lei no 9.790/99 ou o que o administrador casuisticamente entender que seria necessário?

29 Art. 3o Não se aplicam as exigências desta Lei:

III - aos contratos de gestão celebrados com organizações sociais, na forma estabelecida pela Lei no 9.637, de 15 de maio de 1998.

30 BRASIL. Projeto de Lei nº 649, de 2011. Estabelece o regime jurídico das parcerias entre Administração Pública e entidades privadas sem fins lucrativos para a consecução de finalidades de interesse público. p. 47. Disponivel em: <http://www.senado.gov.br/atividade/materia/getPDF.asp?t=98462\&tp=1>. Acesso em: 12 abr. 2015.

31 A distinção das OS, frente às demais, não está no escopo deste trabalho. Para aprofundamento sobre esse tema, recomenda-se a leitura de artigo "Organizações Sociais: Natureza Jurídica da Responsabilidade Civil das Organizações Sociais em Face dos Danos Causados a Terceiros”, elaborado por Cristiana Fortini, disponível em: <http://www.direitodoestado.com/revista/RERE-6-JUNHO-2006-CRISTIANA\%20FORTINI.pdf>.

32 Art. 4 Aplicam-se as disposições desta Lei, no que couber, às relações da administração pública com entidades qualificadas como organizações da sociedade civil de interesse público, de que trata a Lei n 9.790, de 23 de março de 1999, regidas por termos de parceria. 
Ainda sobre a exclusão de aplicabilidade da lei ora comentada, ressalta-se que o inciso II, do artigo $3^{\text {o3 }}$ também exclui do âmbito de incidência dessa lei as transferências voluntárias regidas por lei específica. Contudo, tal dispositivo é excessivamente genérico, não sendo possível identificar qual seria a lei específica que permite transferência voluntária direta a particulares ou quais disposições seriam contrárias à lei geral de parcerias.

Outro aspecto que tem sido objeto de questionamentos, em especial diante do largo conceito de Organização da Sociedade Civil, envolve a incidência ou não dos ditames da Lei no 13.019/2014 sobre os Serviços Sociais Autônomos (SSA).

Com efeito, considerando que a Lei não estabelece, como condição de enquadramento ou não, o mecanismo de criação da entidade, não excetuando entidades oriundas de processo legislativo, a conclusão inicial permitiria afirmar que a Lei no 13.019/14 atinge também os serviços sociais autônomos. A conclusão seria reforçada pelo fato de a Lei no 13.019/14 não empregar a expressão "terceiro setor", bastante para afastar os Serviços Sociais Autônomos, porque nascida para abranger entidades gestadas por particulares de forma a atender propósitos socialmente relevantes e sem intuito especulativo.

Porém, o exame das circunstâncias que conduziram à edição da lei, que dizem respeito a denúncias envolvendo repasse de recursos públicos e fragilidades na escoIha e fiscalização das entidades agraciadas, nenhuma relação possui com os SSA. Não se encontra na justificativa do Projeto de Lei alusão aos SSA como alvos aos quais também se destinaria a lei.

De se notar que os SSA tradicionais, cujo ápice de surgimento remonta à década de 40 do século XX, voltados ao amparo do trabalhador, são distintos dos atuais SSA, que não se prestam a atender determinada categoria funcional, mas voltam-se a colaborar com atividades oferecidas a toda coletividade. Como exemplo de maior visibilidade, destaca-se a Rede Sarah.

São entidades que se originam de vontade político-administrativa. Diversamente do que ocorre com os entes a que a Lei no 13.019/14 se volta, os Serviços Sociais Autônomos não são entidades privadas cujo nascimento decorre de vontade e esforço de indivíduos. Menos ainda nascem com o intuito de disputar espaço com outras entidades.

Abordagem importante a respeito da dualidade de SSAs foi realizada pelo Supremo Tribunal Federal, quando da apreciação do Recurso Extraordinário no $789.874 / D F{ }^{34}$ relatado pelo Ministro Teori Zavaski. Afirma o eminente Ministro:

\footnotetext{
33 Art. 3o Não se aplicam as exigências desta Lei: II - regidas por lei específica, naquilo em que houver disposição expressa em contrário;

34 BRASIL. Supremo Tribunal Federal. RE no 789874, Relator: Min. Teori Zavascki, Tribunal Pleno, julgado em 17.09.2014. Acórdão eletrônico repercussão geral - Mérito DJe-227, Divulgação: 18.11.2014 Publicação: 19.11.2014.
} 
Presentes no cenário brasileiro desde a década de 1940, as entidades integrantes do denominado Sistema "S" resultaram de iniciativa estatal destinada a desenvolver a prestação de certos serviços de elevado valor social. Conferiu-se a entidades sindicais dos setores econômicos a responsabilidade de criar, organizar e administrar entidades com natureza jurídica de direito privado destinadas a executar serviços de amparo aos trabalhadores. Como fonte financiadora desses serviços, atribuiu-se às empresas vinculadas a cada um dos setores econômicos envolvidos a obrigação de recolher uma contribuição compulsória, incidente sobre suas folhas de pagamento.

$[\ldots]$

É importante não confundir essas entidades, nem equipará-las com outras criadas após a Constituição de 1988, cuja configuração jurídica tem peculiaridades próprias. É o caso, por exemplo, da Associação das Pioneiras Sociais - APS (serviço social responsável pela manutenção da Rede SARAH, criada pela Lei 8.246/91), da Agência de Promoção de Exportações do Brasil - APEX (criada pela Lei 10.668/03) e da Agência Brasileira de Desenvolvimento Industrial - ABDI (criada pela Lei 11.080/04). Diferentemente do que ocorre com os serviços autônomos.

$[\ldots]$

Justamente por isso, a doutrina especializada registra e classifica:

"[...] dois tipos distintos de Serviços Sociais Autônomos:

a) aqueles aos quais foi atribuída capacidade tributária para arrecadar e gerir contribuições sociais, e que atuam em uma nova atividade criada pela iniciativa privada para o desenvolvimento de atividades do terceiro setor; e

b) aqueles cuja subsistência decorre de repasses governamentais, decorrentes de receita própria, seja em razão de fundos públicos ou de transferência de empréstimos obtidos interna ou externamente, e que são criados a partir de um órgão público preexistente, assumindo-lhe as funções e que, para sua efetiva implementação como instrumentos da atuação do Estado nesta área, devem estar acompanhados de contrato de gestão. (SCAFF, Fernando Facury. Contrato de Gestão, serviços sociais autônomos e intervenção do Estado. Interesse Público - IP, Belo Horizonte, ano 3, n. 12, out./dez. 2001)

Bem se vê, portanto, que ao contrário dos serviços autônomos do primeiro grupo, vinculados às entidades sindicais (SENAC, SENAI, SEST, SENAT e SENAR), os do segundo grupo (APS, APEX e ABDI) não são propriamente autônomos, pois sua gestão está sujeita a consideráveis restrições impostas pelo poder público, restrições que se justificam, sobretudo, porque são financiadas por recursos do próprio orçamento federal. Essas limitações atingem, inclusive, a política de contratação de pessoal dessas entidades. Tanto a lei que autorizou a criação da APS, quanto aquelas que implementaram a APEX e a ABDI têm normas específicas a respeito dos parâmetros a serem observados por essas entidades nos seus processos seletivos e nos planos de cargos e salários de seus funcionários (ex: art. 3oㅡ VIII e IX, da Lei 8.246/91, art. 9으, V e VI da Lei 10.668/03 e art. 11, $\S \S 2^{\circ}$ e $3^{\circ}$ da Lei $\left.11.080 / 04\right)$ 
A diferença entre os dois Serviços Sociais autônomos não parece interferir quando em questão a não influência da Lei no 13.019, ao menos não no que toca à questão da seleção das entidades e ao chamamento público.

Em todos os casos, os serviços sociais autônomos são entidades que se originam de vontade político-administrativa. Por trás do seu nascimento, há sempre a lei. 0 Estado está, ao patrocinar sua criação, interessado na existência de uma pessoa que, embora não pertença ao aparato estatal, não pode ser comparada a um privado. Por isso, a expressão paraestatal a designar a condição peculiar das citadas entidades.

Outro ponto demanda atenção: tendo o legislador especificado que essa lei se aplica apenas às Organizações da Sociedade Civil que não tenham fins lucrativos, qual será o tratamento estendido aos ajustes que tenham particulares de natureza lucrativa, mas que nessa determinada relação jurídica não tenham como objetivo esse fim? Esses ajustes permaneceriam no âmbito do artigo 116 da Lei no 8.666/93?

Sob a ótica da consecução do interesse público, conforme leciona Gustavo Magalhães, ${ }^{35}$ é possível que particulares com fins lucrativos figurem nessas espécies de acordos, desde que, para a execução do objeto específico, o colaborador atue de forma desinteressada de lucro, não exigindo, portanto, qualquer contrapartida financeira para realização da atividade social. Parece-nos relevante que a ação desinteressada, que esses ajustes exigem, cinja-se ao fim lucrativo destes, e não à natureza jurídica, em si, do colaborador.

Nesse sentido, tendo a lei expressamente delimitado seus destinatários, não se aplicariam as disposições desse instrumento legal a situações desse viés. Contudo, por vezes a disciplina contida no art. 116 da Lei no 8.666/1993 pode não ser suficiente, especialmente por ter como pressuposto ajustes que importam no repasse de recursos aos particulares, restando vácuo normativo sobre o tema.

Desta sorte, em razão da falta de densidade normativa da matéria, e dos beneficios à consecução do interesse público, parece relevante aplicar, ainda que de forma não exclusiva, a principiologia que alicerça nova lei, em especial o que reforça a necessidade de transparência e impessoalidade.

Além disso, salta a atenção que o artigo 33 impõe às entidades que objetivam firmar parcerias com a Administração Pública alguns requisitos rígidos quanto às regras estatutárias: (i) previsão do objeto voltado à consecução de atividades com cunho social; (ii) constituição de conselho fiscal ou órgão equivalente; (iii) previsão de transferência do patrimônio líquido, no caso de dissolução, a outra pessoa jurídica de igual natureza e preferencialmente de objeto social semelhante; (iv) estabelecimento de normas de prestação de contas sociais, que observem as Normas Brasileiras de Contabilidade e que deem ampla publicidade às contas anuais.

\footnotetext{
35 MAGALHÃES, Gustavo Alexandre. Convênios Administrativos. Aspectos polêmicos e análise crítica de seu regime jurídico. São Paulo: Atlas, 2012. p. 70.
} 
Além disso, são elegíveis, para fins dessa lei, as instituições constituídas há, no mínimo, três anos, ${ }^{36}$ que comprovem experiência na realização do objeto da parceria almejada ${ }^{37}$ e que comprovem a capacidade técnica e operacional para o cumprimento das metas estabelecidas no ajuste. ${ }^{38}$

A respeito da exigência de tempo prévio de constituição, cabe ponderar que o requisito isoladamente não se presta a acautelar o interesse público. A mera existência por três anos nada significa. 0 que importa, se o que se pretende é afastar aventureiros, está na alínea "b" do início VII do art. 24, qual seja, a experiência prévia na realização, com efetividade, do objeto da parceria ou de natureza semelhante. $E$, para tal requisito, não se impôs período mínimo. Logo, parece inconveniente exigir que a OSC tenha 3 anos de existência, com cadastro ativo, quando o que se deve examinar é acúmulo de experiência. 0 inconveniente se agravará, em casos concretos, quando se perceber a ausência de entidades que consigam cumprir a alínea "a", embora cumpram os demais requisitos.

Ressalta-se que tempo mínimo de existência não constava do PL № 649/11, mas já era previsto na Portaria Interministerial oㅜ 507/2011. ${ }^{39}$ Claramente, a União quer expandir sua decisão política aos demais entes federados. Vê-se também que esse requisito não está presente na Lei no 9.637/98 e na Lei oํ 9.790/99, que disciplinam, respectivamente, na esfera federal as Organizações Sociais e Organizações da Sociedade Civil de Interesse Público. ${ }^{40}$

A comparação entre o PL e a Lei no 13.019/14 também permite constatar que as alíneas "b" e "c" do art. $24, \S 1^{\circ}$, VII, que hoje criam condicionantes para que a OSC possa participar do chamamento, antes estavam posicionadas como critérios de julgamento obrigatório (art. 26 do PL).

Com efeito, no PL no 649/11 original, seis eram os critérios de julgamento obrigatórios. Na Lei no 13.019/14, o artigo que se dedica ao assunto (art. 27) preservou apenas dois dos seis critérios obrigatórios de julgamento: (i) o grau de adequação da proposta aos objetivos específicos do programa em que se insere o tipo de parceria e (ii) ao valor de referência constante do chamamento público. Dos outros quatro critérios, dois outros foram alocados exatamente nas alíneas "b" e "c", antes comentados.

\footnotetext{
Art. $24, \S 1^{\circ}$, VII, "a”, da citada lei.

37 Art. 24, §1ำVII, “b”, da citada lei.

38 Art. 24, §1ํㅡ, VII, "c", da citada lei.

39 Art. 8ำ §1ํ․ O edital do chamamento público ou concurso de projetos conterá, no mínimo, as seguintes informações: IV - exigência de declaração da entidade proponente de que apresentará, para celebração do instrumento, comprovante do exercício, nos últimos 3 (três) anos de atividades referentes à matéria objeto do convênio ou termo de parceria que pretenda celebrar com órgão ou entidade, nos termos do $\S 7^{\circ}$ deste artigo;

40 Em verdade, a Lei o 9.637/98 e a Lei no 9.790/99 não fixam, também, exigências de expertise anterior ou demonstração de capacidade técnica e operacional.
} 
Nesse ponto, indaga-se: qual o destino dos outros dois? Um dos critérios de julgamento sugeridos no PL foi suprimido. Referia-se ao valor da contrapartida financeira. A Lei ㄲo 13.019/14 suprimiu a contrapartida financeira (art. 35, §1ํㅡ). 0 último critério a que o art. 26 do PL aludia está previsto no art. 34, IV, da Lei no 13.019/14. Ao invés de considerá-lo como critério obrigatório de julgamento, a Lei exige, para celebração das parcerias, que as OSC apresentem documento que evidencie a situação das instalações e as condições materiais da entidade, quando essas instalações e condições forem necessárias para a realização do objeto pactuado. Ou seja, todas as OSC deverão comprovar a adequação das instalações e das condições materiais, se isso for necessário à concretização do objeto.

Como forma de ampliar a participação, a lei possibilita a participação de Organizações Sociais de forma coligada, desde que a associação seja compatível com a execução do objeto do ajuste e expressamente permitida pelo edital. Para tanto, a instituição responsável deverá ter ao menos cinco anos de constituição perante a Receita Federal e experiência na consecução do objeto por, pelo menos, três anos (art. 25). Ou seja, o lapso temporal de prévia existência é ainda maior do que o fixado no art. 24. Além disso, no momento de celebração do ajuste, deverão ser indicadas todas as organizações que executarão, ainda que de forma supletiva, o objeto, não podendo essa lista ser alterada sem o prévio consentimento da Administração Pública.

A atuação em rede assemelha-se a uma espécie de consórcio entre as entidades. Entretanto, o fato de uma entidade celebrante assumir a "integral responsabilidade" reflete regramento diverso do constante na Lei no $8.666 / 93$. Isso porque, ao disciplinar o consórcio, a Lei o 8.666/93 (art. 33, V) prevê responsabilidade solidária das integrantes no decorrer da licitação e da execução do contrato.

Por fim, estão expressamente impedidas de figurar nesses ajustes, nos termos do artigo 39 da citada lei, aquelas organizações sociais que não estejam legalmente constituídas ou que não tenham cumprido com o dever de prestar contas em parcerias anteriores. Da mesma forma, não poderão compor esses ajustes as organizações que tenham como dirigente "agente político de Poder ou do Ministério Público, dirigente de órgão ou entidade da administração pública de qualquer esfera governamental, ou respectivo cônjuge ou companheiro, bem como parente em linha reta, colateral ou por afinidade, até o segundo grau".

Além disso, é vedada a celebração dos ajustes previstos nessa lei às instituições com contas rejeitadas nos últimos cinco anos pela Administração Pública, que não tenham sanado a situação e quitado os eventuais débitos, ou que a decisão que rejeitou as contas não tenha sido reformada.

Tem-se ainda a enumeração de diversas situações que culminam na aplicação de sanção, que impedem a participação das organizações sociais, tais como: suspensão para participação em licitação ou declaração de inidoneidade, suspensão para 
participar de chamamento público, nos termos do artigo 73 , incisos II e III da mesma lei, reprovação das contas em outras de parceria, em decisão irrecorrivel nos últimos oito anos, por Tribunal ou Conselho de Contas de qualquer esfera da Federação.

Definidos os principais requisitos para participação do particular no âmbito da Lei no 13.019/2014, passa-se a estudar os contornos das modalidades de parceira previstas pelo marco legal.

\section{Instrumento de formalização das parcerias: Termo de Colaboração e Termo de Fomento}

Com a aprovação da citada lei foram regulamentadas no ordenamento jurídico pátrio duas espécies de acordos entre as organizações da sociedade civil e a Administração Pública: o Termo de Colaboração e o Termo de Fomento.

O Termo de Colaboração é ajuste que formaliza a parceria entre Estado e Organização da Sociedade Civil, para a consecução de interesse público, que tenha sido proposto pela Administração Pública (art. 2º, VII). O Termo de Fomento, por sua vez, tem contornos semelhantes ao ajuste acima descrito, se distinguindo deste apenas por resultar de processo que resulta de proposta formulada pela organização civil (art. 2ㅇ, VIII).

De início, chama a atenção a opção legislativa por adotar nova terminologia aos ajustes antes chamados genericamente de convênios. Na justificativa do projeto de lei o Senador Aloysio Nunes Ferreira revela que a alteração seria necessária, pois o vocábulo "convênio" teria significado genérico, aplicável a qualquer modalidade de acordo no qual as partes possuem o mesmo objetivo. ${ }^{41}$ Por tal motivo, segundo o relatório, optou-se por deixar o vocábulo convênio com sentido específico, abrangendo apenas as parcerias realizadas entre unidades federativas e os "convênios ordinários" e os "convênios de pequeno porte", e adotar o termo "parcerias" como gênero.

Ressalta-se que a Emenda o 2-CMA/CAE, ${ }^{42}$ relatada pelo Senador Rodrigo Rollemberg, eliminou alguns dispositivos sob o pretexto de que a constitucionalidade e juridicidade poderiam ser contestadas. Assim, o então Senador atribuiu nova redação à proposta de lei, excluindo o "convênio ordinário" e o "convênio de pequeno porte" sugeridos no texto original. Diante dessas alterações, a adoção da terminologia "convênio" restaria limitada apenas para as relações entre entes públicos.

\footnotetext{
41 BRASIL. Projeto de Lei nํ 649, de 2011. Estabelece o regime jurídico das parcerias entre Administração Pública e entidades privadas sem fins lucrativos para a consecução de finalidades de interesse público. p. 47/48. Disponível em: <http://www.senado.gov.br/atividade/materia/getPDF.asp?t=98462\&tp=1>. Acesso em: 12 abr. 2015.

42 BRASIL. Emenda 02 substitutiva do Projeto de Lei no 649, de 2011. Estabelece o regime jurídico das parcerias entre Administração Pública e entidades privadas sem fins lucrativos para a consecução de finalidades de interesse público. Disponível em: <http://www.senado.gov.br/atividade/materia/getPDF. asp?t=138397\&tp=1\#Emenda2>. Acesso em: 12 abr. 2015.
} 
Nesse ponto, convém realizar uma crítica, já sinalizada, em certa medida neste trabalho. A alteração terminológica proposta ignora que a Constituição Federal expressamente prevê a existência de convênios realizados entre entes públicos e privados, nos termos do artigo 199, bem como que o artigo 116 da Lei no 8.666/1993 permanece em vigor. Assim, não parece possível cogitar da eliminação da expressão "convênios" ou mesmo de sua realização. No mínimo, ainda seria possível cogitar de convênios entre entes estatais e empresas, incumbidos de objetivos comuns, ausente finalidade lucrativa.

Quanto à escolha entre as duas espécies de parcerias, ressalta-se que essa será definida de parte que propuser o plano de trabalho. Nesse sentido, observa-se a aproximação desses instrumentos a figuras já aplicáveis às concessões e Parcerias Público-Privadas, para permitir maior participação da iniciativa privada nos estudos e estruturação dos futuros projetos. Considerando o disposto no art. 21 da Lei no $8.987 / 95$, os entes federados têm regulamentado e utilizado procedimentos cujos nomes oscilam, mas que visam formalizar a cooperação privada, na construção da licitação, por entidades que porventura podem integrar o rol de licitantes, no futuro. ${ }^{43}$ $\mathrm{Na}$ esfera federal, prevê-se a Manifestação de Interesse da Iniciativa Privada (MIP), situação em que os particulares propõem projetos e soluções e o Procedimento de Manifestação de Interesse (PMI), por intermédio do qual a Administração Pública apresenta suas prioridades com o objetivo de receber estudos, levantamentos e projetos para consecução destas.

Importa destacar, que os artigos 16 e 17 da mesma lei impõem que esses acordos serão celebrados sempre que houver transferência voluntária de recursos com fim à consecução do plano de trabalho proposto, devendo ser precedido, em regra, de chamamento público.

A menção à transferência de recursos não se coaduna com o artigo inaugural da Lei. 0 art. 1ํ da Lei o 13.019/14 define que se aplicam as normas gerais da presente lei às parcerias que envolvam ou não a transferência voluntária de recursos.

A formalização desses ajustes dependerá de parecer de órgão técnico (art. 35, V) da Administração Pública, que deverá se pronunciar expressamente quanto ao mérito da proposta, a reciprocidade de interesse na celebração do ajuste, viabilidade da execução e dos valores estimados, dos meios disponíveis para execução e da designação de comissão para avaliação. Ao menos em uma análise inicial, soa estranha a localização do dispositivo em comento. Exigir parecer técnico que envolva o mérito da proposta, como condição para celebração dos Termos de Comento ou Colaboração, quando, ao menos pelo que se extrai da organização da lei, já se abordou o chamamento público. Estaria o legislador cogitando de um parecer técnico após

\footnotetext{
430 atual Decreto Federal n ․428/15 prevê o procedimento de manifestação de interesse e a manifestação de interesse da iniciativa privada.
} 
o chamamento público? Se sim, cabe, após o chamamento, investigar o "mérito da proposta" como menciona o art. $35, \mathrm{~V}$, "a"?

Além disso, faz-se necessário parecer jurídico, emitido pelo órgão de assessoria ou consultoria da Administração Pública, atestando o cumprimento dos requisitos exigidos no âmbito da Lei no 13.019/2014. Trata-se de dispositivo que reflete regra semelhante na Lei o 8.666/93 (art. 38, VI).

Quanto ao objeto dos citados ajustes, destaca-se que são vedadas as parcerias $^{44}$ que importem na delegação de atividade regulatória, fiscalizatória ou outras exclusivas do Estado, ${ }^{45}$ bem como de prestação de serviços ou atividades que tenham como destinatário final o aparelho administrativo do Estado.

Da mesma forma, não poderão ser objeto desses ajustes serviços de apoio administrativo. Tais vedações expressam a preocupação do legislador de que os ajustes tenham, de fato, consecução de fim social, e não de atividades que deveriam atrair o regime contratual administrativo, mas que, em razão do regime mais flexível, tentam enquadrar-se como parcerias. Além disso, pressupõe-se estar no âmbito da atividade de fomento, sendo, portanto, atividade em caráter suplementar, sob o risco de se ter uma formalização de parceria à substituição de verdadeiro contrato de prestação de serviço. ${ }^{46}$

A citada lei expressamente veda a criação de novas modalidades de parcerias entre a Administração Pública e os particulares, bem como a combinação das diferentes modalidades previstas nesta lei. Em que pese tal determinação, a própria lei ressalva de que tal não implica qualquer prejuízo aos termos de gestão e de parceria, previstos nas Leis $n^{\circ 5} 9.637 / 1998$, e 9.790/1999, que permanecem com os contornos definidos pelas leis específicas.

Por fim, destaca-se que a lei impõe à Organização da Sociedade Civil indicar no instrumento de formalização da parceria um dirigente que se responsabilizará solidariamente à instituição pela execução e cumprimento das metas definidas no ajuste. ${ }^{47}$

44 Art. 40. É vedada a celebração de parcerias previstas nesta Lei que tenham por objeto, envolvam ou incluam, direta ou indiretamente:

I - delegação das funções de regulação, de fiscalização, do exercício do poder de polícia ou de outras atividades exclusivas do Estado;

II - prestação de serviços ou de atividades cujo destinatário seja o aparelho administrativo do Estado.

Parágrafo único. É vedado também ser objeto de parceria:

I - a contratação de serviços de consultoria, com ou sem produto determinado;

II - o apoio administrativo, com ou sem disponibilização de pessoal, fornecimento de materiais consumíveis ou outros bens.

45 As vedações são, em certa medida, semelhantes às constantes da Lei no 11.079/04 (PPP) e da IN nำ2/08 do Ministério do Planejamento Orçamento e Gestão.

46 MAGALHÃES, Gustavo Alexandre. Convênios Administrativos. Aspectos polêmicos e análise crítica de seu regime jurídico. São Paulo: Atlas, 2012. p. 100 e 101.

47 Art. 37. A organização da sociedade civil indicará ao menos 1 (um) dirigente que se responsabilizará, de forma solidária, pela execução das atividades e cumprimento das metas pactuadas na parceria, devendo essa indicação constar do instrumento da parceria. 
Interessante que, enquanto a Lei no 13.019/14 estabelece a responsabilidade da pessoa física pelo que seria atribuível à pessoa jurídica, a Lei Anticorrupção Empresarial prevê a responsabilização da pessoa jurídica por atos cometidos pelo seu corpo funcional. Ainda diferentes, essas determinações vislumbram o mesmo objetivo: responsabilização tanto da pessoa jurídica quanto dos dirigentes por atos contrários à legislação pertinente.

\section{Obrigatoriedade de seleção das Organizações da Sociedade Civil por Chamamento Público}

A citada lei encerra no âmbito doutrinário acaloradas discussões sobre a necessidade ou não de realização de procedimento licitatório para a celebração de convênios entre a Administração Pública.

Isto porque o entendimento majoritário da doutrina era de que o trecho "no que couber", do artigo 116 da Lei no 8.666/1993 não importava a aplicação do regime contratual administrativo aos convênios. Dessa forma, a obrigatoriedade de licitação para celebração dos contratos não alcançaria, necessariamente, os convênios. ${ }^{48}$

Contudo, interessantes questionamentos a tal posicionamento foram suscitados nos últimos anos, principalmente em relação à inexistência de distinção quanto à natureza jurídica dos convênios, apta a afastar o dever de licitar, insculpido no art. 37, XXI, e insuficiência do discurso de inviabilidade de competição e inexistência de fim lucrativo das entidades de Terceiro Setor, para justificar a criação de prerrogativas no que tange à celebração desses ajustes.

Ocorre que a possibilidade de se preterir uma organização privada em favor de outra (ou um determinado interesse em detrimento de outro) efetiva-se legitimamente apenas quando há um procedimento administrativo lícito e idôneo capaz de selecionar a organização privada que melhor atenderá aos fins do próprio convênio. Não poderia ser afastada a incidência do regime jurídico-administrativo sobre as relações do Estado com o terceiro setor com base na premissa de que a entidade particular atua de forma cooperada a fim de se atingir um interesse público.

Reconhecendo que às relações de fomento aplica-se o princípio da isonomia, e que não há motivo apto a ensejar esses privilégios, a Lei no 13.019/2014 impõe como regra a realização de Chamamento Público para a formalização desses ajustes,

\footnotetext{
48 Nesse sentido, destaca Marçal Justen Filho: “Mesmo quando algum particular participa do convênio, a licitação não se faz necessária porque as partes do convênio não visam extrair algum benefício pessoal a partir da execução da avença. Logo, a natureza não interessada e destituída de cunho egoístico conduz à possibilidade, teórica, de todos os possíveis interessados comprometerem seus esforços recursos para a satisfação de necessidades administrativas". Destaca-se que o citado professor, em seguida defende que caso haja situação de exclusão em relação a quem celebrará o ajuste, poderá ser obrigatório um procedimento seletivo (JUSTEN FILHO, Marçal. Comentários à Lei de Licitações e Contratos Administrativos. 14. ed. São Paulo: Dialética, 2010. p. 935).
} 
reservando uma inteira seção para pormenorizar de que forma será realizada a seleção dos interessados em se associar à Administração. Destaca-se que a determinação de Chamamento Público, como método de seleção de instituições do Terceiro Setor, já possuía alicerce no art. 4 음 do Decreto o 6.170/2007, ${ }^{49}$ contudo, tal determinação era oponível necessariamente apenas nos casos que envolvessem a transferência de recursos ou a descentralização de créditos oriundos dos Orçamentos Fiscal e da Seguridade Social da União.

De forma geral, o artigo 23 expõe que deverão ser adotados procedimentos claros, objetivos, que orientem os interessados e facilitem o acesso direto aos órgãos da administração pública, independentemente da modalidade de parceria que será objeto do certame. O edital para o Chamamento Público deverá conter, no mínimo, informações sobre objeto, programação orçamentária, prazos e condições para a celebração do ajuste, datas e critérios de julgamento das propostas, além das exigências quanto à constituição das organizações civis, que foram tratadas no tópico anterior.

Quanto ao procedimento de Chamamento Público, foi prevista a inversão de fases, sendo o julgamento do grau de adequação da proposta aos objetivos específicos do ajuste precedente à etapa de verificação documental, conforme determinação do artigo 28 da citada lei.

Em que pese à realização de Chamamento Público ser a tônica desse regime jurídico, foram previstas hipóteses de dispensa e inexigibilidade desse procedimento de seleção.

Quanto à inexigibilidade, a Lei oㅡ 13.019/2014, de certa forma, a reproduzir os termos do artigo 25 da Lei oㅡ 8.666/93, dispondo que a inviabilidade de competição, em razão da natureza singular do objeto do plano de trabalho ou quando as metas necessárias à execução do objeto, poderão afastar a obrigatoriedade de procedimento de seleção.

Por sua vez, a dispensa de chamamento público poderá ser invocada nos casos de: (i) urgência decorrente de paralisação ou iminência de paralisação de atividades de relevante interesse público realizadas no âmbito de parceria já celebrada; (ii) guerra ou grave perturbação da ordem pública, desde que o ajuste tenha como objeto atividade de natureza continuada nas áreas de assistência social, saúde ou educação; ou (iii) quando o ajuste tiver por objeto a realização de programa de proteção a pessoas ameaçadas ou em situação que possa comprometer a sua segurança. Importa destacar que, por veto presidencial, seguinte hipótese de dispensa de licitação foi retirada da redação:

\footnotetext{
${ }^{49}$ Art. 4ำ-A celebração de convênio ou contrato de repasse com entidades privadas sem fins lucrativos será precedida de chamamento público a ser realizado pelo órgão ou entidade concedente, visando à seleção de projetos ou entidades que tornem mais eficaz o objeto do ajuste.
} 
Art. 30. A administração pública poderá dispensar a realização do chamamento público:

$[\ldots]$

IV - nos casos em que, no momento da dispensa, o objeto do termo de fomento ou de colaboração esteja sendo realizado adequadamente pela mesma organização da sociedade civil, ininterruptamente, há pelo menos 5 (cinco) anos e as respectivas prestações de contas da aplicação de recursos públicos tenham sido devidamente aprovadas.

A justificativa apresentada para alicerçar o veto presidencial do inciso transcrito foi a de que este dispositivo poderia perpetuar a execução de parcerias com as mesmas instituições sem a necessidade de Chamamento Público, em dissonância com o espírito geral do texto.

Nesse caso, parece-nos acertado o referido veto, tendo em vista que a hipótese retirada da lei reduziria a aplicação da obrigatoriedade de Chamamento Público apenas às instituições que, todavia, não possuem vínculo prolongado com a Administração, tratando-se de verdadeira assimetria de tratamento. E mais, nos casos em que a paralisação do serviço seja iminente, e que possa causar graves prejuízos ao interesse público, a Administração poderá justificar a dispensa pelo inciso I do mesmo artigo, não sendo o argumento de que a prestação do objeto é realizada adequadamente suficiente para afastar o dever geral de realização de procedimento de seleção.

Por todo o exposto, verifica-se que a imposição do Chamamento Público, como regra geral para a seleção das organizações sociais, concretiza as diretrizes constitucionais de isonomia e impessoalidade, dando maior legitimidade às seleções das entidades do Terceiro Setor.

\section{Conclusões}

A Lei no 13.019/2014 institui o marco regulatório para as relações de colaboração, estabelecendo parâmetros com o intuito de conferir maior legitimidade e transparência aos ajustes firmados entre os entres públicos e privados em todas as esferas de poder.

A despeito da intenção que perpassa a lei, a União não tem competência para criar normas gerais para ajustes celebrados entre entidades públicas e privados, tendo como fundamento exclusivamente o art. 22, XXVII, da Constituição Federal, considerando a existência de convênios genuínos, nos quais não se observa a oposição de objetivos, bem como a previsão no texto constitucional que as instituições privadas podem firmar convênios. Nesse sentido, ficaria afastada a aplicação do art. 22, XXVII, da Constituição Federal, sendo a Lei no 13.019/2014 oponível tão somente ao âmbito da Administração Pública Federal. 
Ressalta-se que a lei em questão cria as figuras do Termo de Colaboração e do Termo de Fomento. O primeiro formalizaria a parceria entre Estado e Organização da Sociedade Civil, para a consecução de interesse público, que tenha sido proposto pela Administração, enquanto o segundo, com contornos semelhantes, se distingue deste apenas por iniciar por proposição da organização civil (art. 2ำ VIII).

Em ambos os casos ficam determinados rígidos critérios para formalização, execução e controle desses ajustes, tais como necessidade de chamamento público, ampla publicidade dos ajustes, elaboração de parecer jurídico atestando o mérito da proposta e viabilidade da execução do projeto, bem como a responsabilização solidária do dirigente da entidade privada, materializando, desta forma, parâmetros coerentes com os princípios do regime jurídico-administrativo.

The legal regime of Partnerships between Public Administration and Third Sector: innovations of Federal Law no 13.019/2014

Abstract: The current study addresses the main aspects of the voluntary partnerships between the Public Administration and the Third Sector, regulated by the Federal Law n¹3.019/2014. This diploma establishes a new legal regime valid for these agreements, declining the provision of the article 116 of Federal Law no 8.666/93 and also defining the concept of "Civil Society Organizations", the criteria for the Public Administration to choose the organization, new types of partnerships and comprehensive rules for the agreements execution, accountability and control. This work initially proposes an analytical review on the constitutionality of this law, to subsequently describe the main innovations brought by this legal diploma. The study explores the new regulatory framework applicable to the partnerships established between Public Administrations and the Third Sector, pointing out its importance for transparency and legitimacy of such partnerships. Nevertheless, the Congress legislative competence to address a general rule is questioned for this matter.

Key words: Non profit organizations. Voluntary Partnerships. Public Administration. Third Sector.

\section{Referências}

BERCOVICl, Gilberto. Revolution trough Constitution: the Brazilian's directive Constitution debate. Revista de Investigações Constitucionais, Curitiba, v. 1, n. 1, p. 7-18, jan./abr. 2014.

BRASIL. Constituição da República Federativa do Brasil: promulgada em 5 de outubro de 1988. 44. ed. São Paulo: Saraiva, 2010.

BRASIL. Emenda $n^{\circ} 02$ - CMA-Substitutiva do Projeto de Lei $n^{\circ}$ 649, de 2011. Estabelece o regime jurídico das parcerias entre Administração Pública e entidades privadas sem fins lucrativos para a consecução de finalidades de interesse público. Disponível em: <http://www.senado.gov.br/atividade/ materia/getPDF.asp?t=138397\&tp=1\#Emenda2>. Acesso em: 12 abr. 2015.

BRASIL. Lei $n^{\circ}$ 13.019, de 31 de julho de 2014. Estabelece o regime jurídico das parcerias voluntárias, envolvendo ou não transferências de recursos financeiros, entre a administração pública e as organizações da sociedade civil, em regime de mútua cooperação, para a consecução de finalidades de interesse público; define diretrizes para a política de fomento e de colaboração com organizações da sociedade civil; institui o termo de colaboração e o termo de fomento; e altera as Leis ํㅗ 8.429 , de 2 de junho de 1992, e 9.790, de 23 de março de 1999. 
BRASIL. Lei no 8.666, de 21 de junho de 1993. Regulamenta o art. 37, inciso XXI, da Constituição Federal, institui normas para licitações e contratos da Administração Pública e dá outras providências.

BRASIL. Senado Federal. Projeto de Lei no 649/2011, que estabelece o regime jurídico das parcerias entre a Administração Pública e as entidades privadas sem fins lucrativos para a consecução de finalidades de interesse público. Disponível em: <http://www.senado.gov.br/atividade/materia/ getPDF.asp?t=98462\&tp=1>. Acesso em: 12 abr. 2015.

BRASIL. Supremo Tribunal Federal. RE 789874, Relator: Min. Teori Zavascki, Tribunal Pleno, julgado em 17.09.2014, Acórdão eletrônico repercussão geral - Mérito DJe-227, Divulgação: 18.11.2014, Publicação: 19.11.2014.

CARVALHO FILHO, José dos Santos. Manual de direito administrativo. 5. ed. São Paulo: Atlas, 2012.

CARVALHO, Raquel Melo Urbano. Parecer no 15.383. Disponível em: <http://www.age.mg.gov.br/ images/stories/downloads/advogado/pareceres2014/parecer-15.383.pdf >. Acesso em: 14 abr. 2015.

CHEVALLIER, Jacques. O Estado Pós-Moderno. Belo Horizonte: Fórum, 2009.

DI PIETRO, Maria Sylvia Zanella. Direito Administrativo. São Paulo. Atlas, 2012.

DI PIETRO, Maria Sylvia Zanella. Parcerias na administração pública: concessão, franquia, terceirização, parceria público-privada e outras formas. 8. ed. São Paulo: Atlas.

FORTINI, Cristiana. Contratos Administrativos: Franquia, Concessão, Permissão e PPP. 2. ed. São Paulo: Atlas, 2009.

FORTINI, Cristiana. Organizações Sociais: Natureza Jurídica da Responsabilidade Civil das Organizações Sociais em Face dos Danos Causados a Terceiros. Revista Eletrônica sobre Reforma do Estado, Salvador, n. 6, jun.-ago. 2006. Disponível em: <http://www.direitodoestado.com/revista/RERE-6JUNHO-2006-CRISTIANA\%2OFORTINI.pdf>. Acesso em: 20 maio 2015.

HACHEM, Daniel Wunder. A noção constitucional de desenvolvimento para além do viés econômico: reflexos sobre algumas tendências do Direito Público brasileiro. A\&C - Revista de Direito Administrativo \& Constitucional, Belo Horizonte, ano 13, n. 53, p. 133-168, jul./set. 2013.

JUSTEN FILHO, Marçal. Comentários à Lei de Licitações e Contratos Administrativos. 14. ed. São Paulo: Dialética, 2010.

JUSTEN FILHO, Marçal. Curso de direito administrativo. 6. ed. rev. e atual. Belo Horizonte: Fórum, 2010.

MAGALHÃES, Gustavo Alexandre. Convênios Administrativos. Aspectos polêmicos e análise crítica de seu regime jurídico. São Paulo: Atlas, 2012.

NOBRE JÚNIOR, Edilson Pereira. Uma ideia de Constituição. Revista de Investigações Constitucionais, Curitiba, v. 1, n. 1, p. 111-145, jan./abr. 2014.

NOHARA, Irene Patrícia. Desafios jurídicos das Parcerias Público-Privadas (PPPS) e desenvolvimento nacional sustentável. Revista de Direito Econômico e Socioambiental, Curitiba, v. 5, n. 2, p. 184-203, jul./dez. 2014.

PLACHA, Gabriel. Os impactos e as perspectivas da regulação estatal sobre as atividades econômicas. Revista de Direito Econômico e Socioambiental, Curitiba, v. 1, n. 2, p. 251-270, jul./dez. 2010.

RODRÍGUEZ-ARANA MUÑOZ, Jaime. El Estado autonómico y los nacionalismos. Revista de Investigações Constitucionais, Curitiba, v. 1, n. 3, p. 91-103, set./dez. 2014. 
SUNDFELD, Carlos Ari; SOUZA, Rodrigo Pagani de. As modernas parcerias públicas com o Terceiro Setor. A\&C - Revista de Direito Administrativo \& Constitucional, Belo Horizonte, ano 11, n. 43, p. 57-89, jan./mar. 2011.

Informação bibliográfica deste texto, conforme a NBR 6023:2002 da Associação Brasileira de Normas Técnicas (ABNT):

FORTINI, Cristiana; PIRES, Priscila Giannetti Campos. 0 regime jurídico das Parcerias Voluntárias com as Organizações da Sociedade Civil: inovações da Lei no 13.019/2014. A\&C - Revista de Direito Administrativo \& Constitucional, Belo Horizonte, ano 15, n. 61, p. 93-116, jul./set. 2015.

Recebido em: 26.05.2015

Aprovado em: 02.07.2015 